\title{
The effect of development of ethical leadership on organizational adaptability capacity, education and training organization - case study: ILKHCHI city of Iran
}

\author{
1 Bonab Branch, Islamic Azad University, BONAB, Iran. \\ 2 Bonab Branch, Islamic Azad University, BONAB, Iran. \\ 3 Young Researchers and Elite Club, ILKHCHI branch, Islamic Azad University, ILKHCHI, Iran. \\ E-mail: scholar.tabriz@gmail.com
}

Golamreza Rahimi ${ }^{1}$, Nader Bohlooli ${ }^{2}$ and Tohid Eskandarzadeh ${ }^{3}$

\begin{abstract}
The aim of this study is to examine the impact of ethical leadership on organizational adaptability capacity, the city therefore is education. For this purpose, the factors affecting organizational adaptability in five dimensions based on the individual's orientation, organizational justice, power sharing, ethical conduct, transparency and organizational integration is defined roles. The population of the study, employees of city is therefore, the number of 1407 people, therefore Cochran sampling formula was used to calculate the sample size, the sample includes an estimated 302 people and to select a sample of the statistical population stratified random sampling method is used. The data collected, the questionnaire whose validity and reliability, the samples were analyzed. To analyze the data collected from descriptive and inferential statistical methods were used. Thus, classifying, summarizing and interpreting the data, descriptive statistics and then determine the normality of the data by the Kolmogorov-Smirnov inferential statistics to test hypotheses, and linear regression was used to determine the effect of the test. The results indicate that the hypothesis was confirmed, indicating that the components of the individual's orientation, organizational justice, power sharing, moral guidance, role clarity and organizational integration of organizational adaptability 98 percent of changes in education is explained and the city ILKHCHI it has an effect. the results show that the attention is given to ethical leadership, organizational adaptability capacity increases in education Ilkhchi city. And findings with the findings of Golparvar, colleagues, Abbas-Zadeh and Bvdaqy is consistent.
\end{abstract}

Keywords: Education. Ethical leadership. Organizational adaptability. Organizational integration. Population.

\section{INTRODUCTION}

Leadership has been defined as an issue that has long attracted the attention of researchers and the public as a process of influencing and directing individuals toward achieving goals. Perhaps the reason for the widespread attractiveness of leadership is that it is a very mysterious process that ex- ists in everyone's lives 1]. Leadership is one of the essential requirements for the activities of many modern organizations. In particular, recent business scandals in business have raised questions about the role of leadership in shaping ethical behavior.

In the present century, organizations are increasingly faced with dynamic and changing environments that, in order to survive, 
have to adapt themselves to environmental changes. In today's world, change is fast and successful adaptation is an important part of success in the present age [3] with regarding the increasing rate of change in scientific, technological, social, and so on, today's organizations are considered to be successful organizations that have high organizational adaptability capacity. According to Connolly \& York, organizational adaptability capacity is the ability of organizations to learn continuously and respond to changes within and outside the organization which plays a fundamental role in organizational efficiency and effectiveness [2]. The core of the adaptability capacity is innovation, systemic thinking, organizational learning, shared vision, customer orientation, and change [4-6]. Indeed, organizational adaptability capacity is an agent for the survival of an organization, and this concept has a key role in promoting organizational productivity and performance. The present study concentrated on the adaptability capacity of the educational and training organization of Ilkhchi. One of the main reasons for considering adaptability capacity in educational and training system is based on this principle that if the employees of the mentioned organization in the workplace do not have adaptability capacity and adjustment to innovations, changes, etc., their organizational, administrative problems will not solve and, eventually, improvement of organizational performance would be impossible. In this regard, the results of external studies show that there is a significant relationship between the variables of ethical leadership and organizational adaptability [7-8]. However, despite the fundamental role of ethical leadership in enhancing organizational adaptability ca- pacity, it has been neglected in our society. In one sense, the available evidence indicates that no new studies have been conducted in the statistical society with focusing on the capacity of organizational adaptation and ethical leadership and more studies have been done on the variables such as organizational culture and organizational participation [1] and also the relationship between spiritual leadership and the effectiveness of leadership [2] Relationship between leader, follower and creativity (dimension of adaptability capacity ) [4] , The relationship between transitional leadership and organizational culture[7] And the relationship between transitional leadership and performance of companies [5].

The mission of this research is to examine the impact of ethical leadership on organizational adaptability capability with the approach of cognitive behavior and relying on the ethical leadership theory [14], and also with the theory of Denison's adaptability capacity [7] which has not received sufficient attention to these theories and this dimension of leadership in internal investigations. Because organizational adaptability capacity in educational organizations is enhanced when educational managers have characteristics such as modeling, pragmatism, power sharing, ethical guidance, role resolution, and, in a sense, ethical leaders. Therefore, the basic questions of the research are going forward on these factors that firstly, how much is the degree of organizational adaptability among the employees of training and educational system in Ilkhchi city? And secondly, do ethical leadership and its dimensions have any impact on enhancement of organizational adaptability capacity? This research seeks to answer scientifically to these questions 
from different perspectives.

\section{MATERIALS AND METHODS}

\section{Research hypotheses}

The main hypothesis

Ethical leadership has a positive and significant effect on improvement of the organizational adaptability capacity in the training and Educational system of Ilkhchi (Figure 1).

Figure 1. Analytical Model of Research

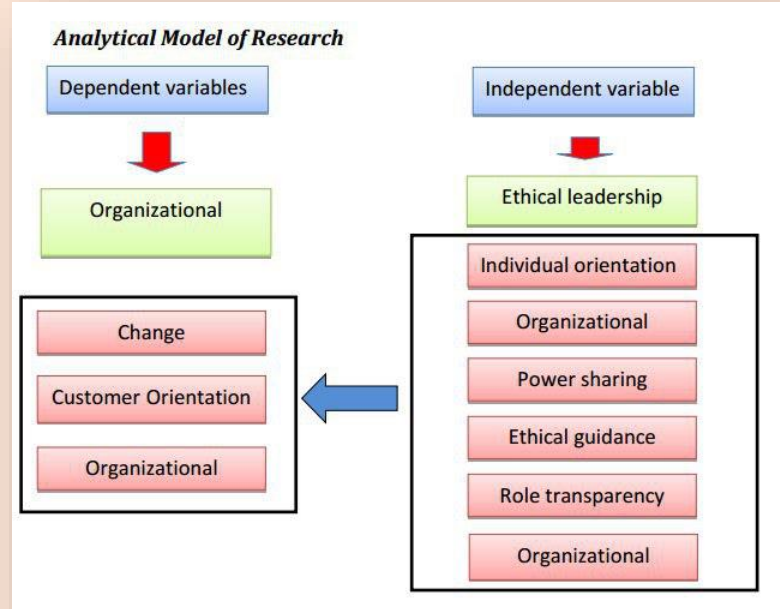

\section{Sub-hypotheses}

Individual orientation has a positive and significant effect on the organizational adaptability capacity in the training and Educational system of Ilkhchi.

Organizational fairness has a positive and significant effect on the organizational adaptability capacity in the training and Educational system of Ilkhchi.

The power sharing has a positive and significant effect on the organizational adaptability capacity in the training and Educa- tional system of Ilkhchi.

Ethical guidance has a positive and significant effect on the organizational adaptability capacity in the training and Educational system of Ilkhchi.

Transparency has a positive and significant effect on the organizational adaptability capacity in the training and Educational system of Ilkhchi.

Organizational integration has a positive and significant effect on the organizational adaptability capacity in the training and Educational system of Ilkhchi.

\section{Research methodology}

Because this research is about describing and studying "what is", therefore, the appropriate research method in this research is descriptive. On the other hand, as this study examines the relationship between several variables in a community, is among the correlation plans. Since in descriptive research, the features of the studied community are examined and tested through the survey, the present research is a descriptive, surveying research and it is applied in terms of the purpose. The survey method is used to investigate the distribution of characteristics of a statistical society. In this way, people are asked questions about their attitudes, behaviors, and opinions and in general, these kinds of studies describe a specific phenomenon in a particular environment which is used to test opinions or answer research questions and include descriptions and conclusions.

There is a variety of tools for data collection through which data can be collected and recorded. In the meantime, we can mention cases such as documentary review (library studies), questionnaires, interviews 
and observations. The researcher must use the appropriate tool to obtain the data required in the research and then with analyzing, processing and converting them into information, test the hypotheses. The main tools in this research are data collection, library studies and standard questionnaires.

In this research, to measure ethical leadership based on individual orientation, organizational fairness, power sharing, ethical guidance, transparency and organizational integrity, 35 items from the model [14] and also for measuring the organizational adaptability capacity, 15 items from the questionnaire provided by Denison [11] have been used.

Data obtained through the collected questionnaire has been investigated and analyzed in three sections with the using descriptive statistics and inferential statistics. So first of all in the first section of this chapter, in order to describe questions of the personality of the statistical sample, the frequency distribution table and the percentage of responses have been used. In the second section, research variables are presented as descriptive statistics and graph through the questions that were asked to measure the desired indexes in each of the research hypotheses. In the third section, after determining the normality of the research data, Regression test has been used to describe the ideas of the statistical sample in relation to the independent and dependent variables of the research which test is rejected or confirmed. If confirmed, the percentage of impact is also determined by Regression. The dependent variable has been analyzed as well as using statistical tables and charts of variable frequency distribution and its dimensions and components.

\section{The distribution of research variables}

In this section, research variables are presented as descriptive statistics through the questions that are presented in each questionnaire for measuring the desired indexes in each research hypothesis Table 1.

Table 1. Descriptive statistics of variables

\begin{tabular}{|c|c|c|c|c|c|c|c|c|}
\hline & & $\begin{array}{l}\text { Adaptabil- } \\
\text { ity }\end{array}$ & \begin{tabular}{|l} 
orienta- \\
tion
\end{tabular} & $\begin{array}{l}\text { Fair- } \\
\text { ness } \\
\end{array}$ & power & Ethics & Role & $\begin{array}{l}\text { Integri- } \\
\text { ty }\end{array}$ \\
\hline \multirow[b]{2}{*}{$\mathrm{N}$} & Valid & 302 & 302 & 302 & 302 & 302 & 302 & 302 \\
\hline & $\begin{array}{l}\text { Miss- } \\
\text { ing }\end{array}$ & 0 & 0 & 0 & 0 & 0 & 0 & 0 \\
\hline \multicolumn{2}{|c|}{ Average } & 56.9934 & 26.5298 & $\begin{array}{r}22.748 \\
3\end{array}$ & $\begin{array}{r}22.761 \\
6\end{array}$ & $\begin{array}{r}26.695 \\
4\end{array}$ & $\begin{array}{r}18.920 \\
5\end{array}$ & $\begin{array}{r}15.178 \\
8\end{array}$ \\
\hline \multicolumn{2}{|c|}{ Middle } & 59 & 28 & 24 & 24 & 27 & 19 & 16 \\
\hline \multicolumn{2}{|c|}{ mode } & 60 & 28 & 21 & 21 & 28 & 20 & 14 \\
\hline \multicolumn{2}{|c|}{$\begin{array}{l}\text { Standard } \\
\text { deviation }\end{array}$} & 10.01626 & 5.00937 & $\begin{array}{r}4.2703 \\
0 \\
\end{array}$ & $\begin{array}{r}4.1575 \\
4 \\
\end{array}$ & $\begin{array}{r}4.5516 \\
5 \\
\end{array}$ & $\begin{array}{r}3.4937 \\
5 \\
\end{array}$ & $\begin{array}{r}2.8168 \\
6 \\
\end{array}$ \\
\hline \multicolumn{2}{|c|}{ Variance } & 100.326 & 25.094 & 18.235 & 17.285 & 20.718 & 12.206 & 7.935 \\
\hline \multicolumn{2}{|c|}{$\begin{array}{l}\text { The lowest } \\
\text { amount }\end{array}$} & 25 & 11 & 9 & 9 & 13 & 7 & 6 \\
\hline \multicolumn{2}{|c|}{$\begin{array}{l}\text { The maxi- } \\
\text { mum } \\
\text { amount }\end{array}$} & 75 & 35 & 30 & 30 & 35 & 25 & 20 \\
\hline
\end{tabular}

Inferential analysis of statistical data (test of research hypotheses)

\section{The main hypothesis:}

H1: Ethical leadership has a positive and significant effect on improvement of the organizational adaptability capacity in the training and Educational system of Ilkhchi.

HO: Ethical leadership doesn't have a positive and significant effect on improvement of the organizational adaptability capacity in the training and Educational system of Ilkhchi.

In this study, Regression test has been used to investigate the effect of dependent variable on the independent variable of this hypothesis. 
Table 2. Regression results to determine the effect of ethical leadership on organizational adaptability

\begin{tabular}{|c|c|c|c|c|c|c|c|}
\hline \multicolumn{2}{|l|}{$R$} & $\begin{array}{l}\text { Coeffi- } \\
\text { cient of } \\
\text { detec- } \\
\text { tion }\left(R^{2}\right)\end{array}$ & \multicolumn{3}{|c|}{$\begin{array}{l}\text { justified Coefficient of } \\
\text { detection }\end{array}$} & \multicolumn{2}{|c|}{ standard error } \\
\hline \multicolumn{2}{|c|}{ 0/993 } & 0/985 & \multicolumn{2}{|l|}{ 0/985 } & & \multicolumn{2}{|l|}{1.22361} \\
\hline \multicolumn{2}{|c|}{$\begin{array}{l}\text { Source of } \\
\text { change }\end{array}$} & $\begin{array}{l}\text { De- } \\
\text { grees } \\
\text { of } \\
\text { free- } \\
\text { dom }\end{array}$ & $\begin{array}{l}\text { total of } \\
\text { squares }\end{array}$ & $\begin{array}{l}\text { aver- } \\
\text { age of } \\
\text { square } \\
\text { s }\end{array}$ & $\mathrm{F}$ & $\begin{array}{l}\text { As- } \\
\text { sure } \\
d \\
\text { lev- } \\
\text { el }\end{array}$ & $\begin{array}{l}\text { signif- } \\
\text { icance } \\
\text { level }\end{array}$ \\
\hline \multicolumn{2}{|c|}{ regression } & 1 & $\begin{array}{l}29748.8 \\
17\end{array}$ & $\begin{array}{l}29748 . \\
817\end{array}$ & $\begin{array}{l}16869 . \\
194\end{array}$ & $0 / 95$ & $0 / 000$ \\
\hline $\begin{array}{l}\text { Re- } \\
\text { main } \\
\text { ed }\end{array}$ & $\begin{array}{l}3 \\
0 \\
0\end{array}$ & 449.170 & \multicolumn{2}{|l|}{1.497} & & \multirow{2}{*}{\multicolumn{2}{|c|}{$\begin{array}{l}\text { Test result: } \\
\text { Reject HO hy- } \\
\text { pothesis }\end{array}$}} \\
\hline Total & $\begin{array}{l}3 \\
0 \\
1\end{array}$ & $\begin{array}{l}30197.9 \\
87\end{array}$ & \multicolumn{3}{|l|}{------ } & & \\
\hline
\end{tabular}

As it is considered in Table 2, the significance level of the mentioned test is 0.00 and it can be claimed that the above test is statistically significant with an error of 0.05 or a confidence level of 0.95 . So H1 hypothesis is accepted and $\mathrm{HO}$ hypothesis is rejected. With regards to R2 detection factor which consist of the ratio of the explained changes by the $x$ variable to the total changes that is 0.985 , it can be argued that $98 \%$ of organizational adaptation changes are explained by ethical leadership.

\section{First sub hypothesis:}

H1: Individual orientation has a positive and significant effect on the organizational adaptability capacity in the training and Educational system of ILKHCHI.

HO: Individual orientation doesn't have a positive and significant effect on the organizational adaptability capacity in the training and Educational system of ILKHCHI.

In this study, Regression test has been used to investigate the effect of dependent variable on the independent variable of this hypothesis.
Table 3. Regression results to determine the effect of individual orientation on organizational adaptability

\begin{tabular}{|c|c|c|c|c|c|c|c|}
\hline \multicolumn{2}{|l|}{$R$} & $\begin{array}{l}\text { Coeffi- } \\
\text { cient of } \\
\text { detec- } \\
\text { tion } \\
\text { (R2) } \\
\end{array}$ & \multicolumn{3}{|c|}{$\begin{array}{l}\text { justified Coefficient of } \\
\text { detection }\end{array}$} & \multicolumn{2}{|c|}{ standard error } \\
\hline \multicolumn{2}{|l|}{.955} & .912 & \multicolumn{3}{|l|}{.912} & \multicolumn{2}{|c|}{2.96950} \\
\hline \multicolumn{2}{|c|}{$\begin{array}{l}\text { Source of } \\
\text { change }\end{array}$} & $\begin{array}{l}\text { De- } \\
\text { gree } \\
\text { s of } \\
\text { free } \\
\text { dom }\end{array}$ & $\begin{array}{l}\text { total of } \\
\text { squares }\end{array}$ & $\begin{array}{l}\text { aver- } \\
\text { age of } \\
\text { squares }\end{array}$ & $\mathrm{F}$ & $\begin{array}{l}\text { As- } \\
\text { sure } \\
d \\
\text { level }\end{array}$ & $\begin{array}{l}\text { signifi- } \\
\text { cance } \\
\text { level }\end{array}$ \\
\hline \multicolumn{2}{|c|}{ regression } & 1 & $\begin{array}{l}27552 . \\
603\end{array}$ & $\begin{array}{l}27552 . \\
603\end{array}$ & $\begin{array}{l}3124.6 \\
05\end{array}$ & $0 / 95$ & \\
\hline $\begin{array}{l}\text { Re- } \\
\text { main } \\
\text { ed }\end{array}$ & $\begin{array}{l}3 \\
0 \\
0\end{array}$ & $\begin{array}{l}2645.38 \\
4\end{array}$ & \multicolumn{2}{|l|}{8.818} & & \multirow{2}{*}{\multicolumn{2}{|c|}{$\begin{array}{l}\text { Test result: } \\
\text { Reject HO hy- } \\
\text { pothesis }\end{array}$}} \\
\hline Total & $\begin{array}{l}3 \\
0 \\
1\end{array}$ & $\begin{array}{l}30197.9 \\
87\end{array}$ & 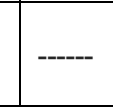 & & & & \\
\hline
\end{tabular}

As it is considered in Table 3, the significance level of the mentioned test is $0 / 00$ and it can be claimed that the above test is statistically significant with an error of 0.05 or a confidence level of 0.95 . So H1 hypothesis is accepted and HO hypothesis is rejected. With regards to R2 detection factor which consist of the ratio of the explained changes by the $x$ variable to the total changes that is $0 / 912$, it can be argued that $91 \%$ of organizational adaptation changes are explained by individual orientation.

\section{Second sub hypothesis:}

H1: Organizational fairness has a positive and significant effect on the organizational adaptability capacity in the training and Educational system of ILKHCHI.

HO: Organizational fairness doesn't have a positive and significant effect on the organizational adaptability capacity in the training and Educational system of ILKHCHI.

In this study, Regression test has been used to investigate the effect of dependent variable on the independent variable of this hypothesis. 
Table 4. Regression results to determine the effect of organizational fairness on organizational adaptability capacity

\begin{tabular}{|c|c|c|c|c|c|c|c|c|}
\hline \multicolumn{2}{|l|}{$\mathrm{R}$} & $\begin{array}{l}\text { Coeffi- } \\
\text { cient of } \\
\text { detec- } \\
\text { tion (R2) }\end{array}$ & \multicolumn{3}{|c|}{$\begin{array}{l}\text { justified Coefficient of } \\
\text { detection }\end{array}$} & \multicolumn{3}{|c|}{ standard error } \\
\hline \multicolumn{2}{|c|}{.977} & .954 & & & & & & 2.16037 \\
\hline \multicolumn{2}{|c|}{$\begin{array}{l}\text { Source of } \\
\text { change }\end{array}$} & $\begin{array}{l}\text { De- } \\
\text { gree } \\
\text { s of } \\
\text { free } \\
\text { dom }\end{array}$ & $\begin{array}{l}\text { total of } \\
\text { squares }\end{array}$ & $\begin{array}{l}\text { ave } \\
\text { age } \\
\text { squ }\end{array}$ & & $\mathrm{F}$ & $\begin{array}{l}\text { As- } \\
\text { sure } \\
d \\
\text { level }\end{array}$ & $\begin{array}{l}\text { signifi- } \\
\text { cance } \\
\text { level }\end{array}$ \\
\hline \multicolumn{2}{|c|}{ regression } & 1 & $\begin{array}{r}28797 . \\
381\end{array}$ & 28 & & $\begin{array}{r}6170.2 \\
79 \\
\end{array}$ & $0 / 95$ & $0 / 000$ \\
\hline $\begin{array}{l}\text { Re- } \\
\text { main } \\
\text { ed }\end{array}$ & $\begin{array}{l}3 \\
0 \\
0\end{array}$ & $\begin{array}{r}1400.15 \\
5\end{array}$ & \multicolumn{2}{|c|}{4.667} & & \multicolumn{3}{|c|}{$\begin{array}{l}\text { Test result: Reject } \\
\text { HO hypothesis }\end{array}$} \\
\hline Total & $\begin{array}{l}3 \\
0 \\
1\end{array}$ & $\begin{array}{r}30197.9 \\
87\end{array}$ & & & & & & \\
\hline
\end{tabular}

As it is seen in Table 4, the significance level of the mentioned test is 0.00 and it can be claimed that the above test is statistically significant with an error of 0.05 or a confidence level of 0.95 . So $\mathrm{H} 1$ hypothesis is accepted and $\mathrm{HO}$ hypothesis is rejected. According to R2 detection factor which consist of the ratio of the explained changes by the $x$ variable to the total changes that is 0.952 , it can be argued that $95 \%$ of organizational adaptation changes are explained by organizational fairness.

\section{Third sub hypothesis:}

$\mathrm{H} 1$ : The power sharing has a positive and significant effect on the organizational adaptability capacity in the training and Educational system of Ilkhchi.

HO: The power sharing doesn't have a positive and significant effect on the organizational adaptability capacity in the training and Educational system of Ilkhchi.

In this study, Regression test has been used to investigate the effect of dependent variable on the independent variable of this hypothesis.
Table 5. Regression Results To determine the power sharing on Organizational Adaptability Capacity

\begin{tabular}{|c|c|c|c|c|c|c|}
\hline \multicolumn{2}{|l|}{$\mathrm{R}$} & $\begin{array}{l}\text { Coeffi- } \\
\text { cient of } \\
\text { detec- } \\
\text { tion } \\
)^{2}(\end{array}$ & \multicolumn{2}{|c|}{$\begin{array}{l}\text { justified Coeffi- } \\
\text { cient of detection }\end{array}$} & \multicolumn{2}{|c|}{ standard error } \\
\hline & .977 & .954 & & .000 & & 2.14944 \\
\hline $\begin{array}{l}\text { Source } \\
\text { of } \\
\text { change }\end{array}$ & $\begin{array}{l}\text { De- } \\
\text { grees } \\
\text { of } \\
\text { free- } \\
\text { dom }\end{array}$ & $\begin{array}{l}\text { total of } \\
\text { squares }\end{array}$ & $\begin{array}{l}\text { average } \\
\text { of } \\
\text { squares }\end{array}$ & $\mathrm{F}$ & $\begin{array}{l}\text { As- } \\
\text { sured } \\
\text { level }\end{array}$ & $\begin{array}{l}\text { signifi- } \\
\text { cance } \\
\text { level }\end{array}$ \\
\hline $\begin{array}{l}\text { regres- } \\
\text { sion }\end{array}$ & 1 & $\begin{array}{r}28811.9 \\
60 \\
\end{array}$ & $\begin{array}{r}28811 . \\
960 \\
\end{array}$ & \multirow{3}{*}{$\begin{array}{r}6236.2 \\
37\end{array}$} & $0 / 95$ & $0 / 000$ \\
\hline $\begin{array}{l}\text { Re- } \\
\text { mained }\end{array}$ & 300 & $\begin{array}{r}1386.02 \\
6 \\
\end{array}$ & 4.620 & & \multirow{2}{*}{\multicolumn{2}{|c|}{$\begin{array}{l}\text { Test result: Reject } \\
\text { HO hypothesis }\end{array}$}} \\
\hline Total & 301 & $\begin{array}{r}30197.9 \\
87 \\
\end{array}$ & & & & \\
\hline
\end{tabular}

As it is seen in Table 5, the significance level of the mentioned test is 0/00 and it can be claimed that the above test is statistically significant with an error of 0.05 or a confidence level of 0.95 . So $\mathrm{H} 1$ hypothesis is accepted and $\mathrm{HO}$ hypothesis is rejected. According to R2 detection factor which consist of the ratio of the explained changes by the $\mathrm{x}$ variable to the total changes that is $0 / 952$, it can be argued that $95 \%$ of organizational adaptation changes are explained by power sharing.

\section{Forth sub hypothesis:}

H1: Ethical guidance has a positive and significant effect on the organizational adaptability capacity in the training and $\mathrm{Ed}$ ucational system of Ilkhchi.

HO: Ethical guidance doesn't have a positive and significant effect on the organizational adaptability capacity in the training and Educational system of Ilkhchi.

In this study, Regression test has been used to investigate the effect of dependent variable on the independent variable of this hypothesis. 
Table 6. Regression Results to Determine Ethical guidance on Organizational Adaptability Capacity

\begin{tabular}{|c|c|c|c|c|c|c|}
\hline \multicolumn{2}{|l|}{$R$} & $\begin{array}{l}\text { Coeffi- } \\
\text { cient of } \\
\text { detec- } \\
\text { tion )R }{ }^{2}(\end{array}$ & \multicolumn{2}{|c|}{$\begin{array}{l}\text { justified Coeffi- } \\
\text { cient of detec- } \\
\text { tion }\end{array}$} & \multicolumn{2}{|c|}{ standard error } \\
\hline & .973 & .946 & & .946 & & 2.32747 \\
\hline $\begin{array}{l}\text { Source } \\
\text { of } \\
\text { change }\end{array}$ & $\begin{array}{l}\text { De- } \\
\text { grees } \\
\text { of } \\
\text { free- } \\
\text { dom }\end{array}$ & $\begin{array}{l}\text { total of } \\
\text { squares }\end{array}$ & $\begin{array}{l}\text { aver- } \\
\text { age of } \\
\text { squar } \\
\text { es }\end{array}$ & $\mathrm{F}$ & $\begin{array}{l}\text { As- } \\
\text { sured } \\
\text { level }\end{array}$ & $\begin{array}{l}\text { signifi- } \\
\text { cance } \\
\text { level }\end{array}$ \\
\hline $\begin{array}{l}\text { regres- } \\
\text { sion }\end{array}$ & 1 & $\begin{array}{r}28572.8 \\
50 \\
\end{array}$ & $\begin{array}{r}106.5 \\
18 \\
\end{array}$ & \multirow{3}{*}{$\begin{array}{r}5274.5 \\
43\end{array}$} & $0 / 95$ & $0 / 000$ \\
\hline $\begin{array}{l}\text { Re- } \\
\text { mained }\end{array}$ & 300 & $\begin{array}{r}1625.13 \\
7 \\
\end{array}$ & $\begin{array}{r}28.13 \\
7 \\
\end{array}$ & & \multirow{2}{*}{\multicolumn{2}{|c|}{$\begin{array}{l}\text { Test result: Reject } \\
\text { HO hypothesis }\end{array}$}} \\
\hline Total & 301 & $\begin{array}{r}30197.9 \\
87 \\
\end{array}$ & & & & \\
\hline
\end{tabular}

As it is seen in Table 6, the significance level of the mentioned test is $0 / 00$ and it can be claimed that the above test is statistically significant with an error of 0.05 or a confidence level of 0.95 . So $\mathrm{H} 1$ hypothesis is accepted and $\mathrm{HO}$ hypothesis is rejected. According to R2 detection factor which consist of the ratio of the explained changes by the $\mathrm{x}$ variable to the total changes that is $0 / 946$, it can be argued that $94 \%$ of organizational adaptation changes are explained by ethical guidance.

\section{Fifth sub hypothesis:}

$\mathrm{H} 1$ : Transparency has a positive and significant effect on the organizational adaptability capacity in the training and Educational system of Ilkhchi.

HO: Transparency doesn't have a positive and significant effect on the organizational adaptability capacity in the training and Educational system of Ilkhchi.

In this study, Regression test has been used to investigate the effect of dependent variable on the independent variable of this hypothesis.
Table 7. Regression Results to Determine Transparency on Organizational Adaptability Capacity

\begin{tabular}{|c|c|c|c|c|c|c|}
\hline \multicolumn{2}{|l|}{$R$} & $\begin{array}{l}\text { Coeffi- } \\
\text { cient of } \\
\text { detec- } \\
\text { tion } \\
\mathrm{R}^{2}(\end{array}$ & \multicolumn{2}{|c|}{$\begin{array}{l}\text { justified Coeffi- } \\
\text { cient of detection }\end{array}$} & \multicolumn{2}{|c|}{ standard error } \\
\hline & .978 & .956 & & .956 & & 2.10057 \\
\hline $\begin{array}{l}\text { Source } \\
\text { of } \\
\text { change }\end{array}$ & $\begin{array}{l}\text { De- } \\
\text { grees } \\
\text { of } \\
\text { free- } \\
\text { dom }\end{array}$ & $\begin{array}{l}\text { total of } \\
\text { squares }\end{array}$ & $\begin{array}{l}\text { average } \\
\text { of } \\
\text { squares }\end{array}$ & $\mathrm{F}$ & $\begin{array}{l}\text { As- } \\
\text { sured } \\
\text { level }\end{array}$ & $\begin{array}{l}\text { signifi- } \\
\text { cance } \\
\text { level }\end{array}$ \\
\hline $\begin{array}{l}\text { regres- } \\
\text { sion }\end{array}$ & 1 & $\begin{array}{r}28874.2 \\
65 \\
\end{array}$ & $\begin{array}{r}28874 . \\
265 \\
\end{array}$ & \multirow{3}{*}{$\begin{array}{r}6543.8 \\
81\end{array}$} & $0 / 95$ & $0 / 000$ \\
\hline $\begin{array}{l}\text { Re- } \\
\text { mained }\end{array}$ & 300 & $\begin{array}{r}1323.72 \\
2 \\
\end{array}$ & 4.412 & & \multirow{2}{*}{\multicolumn{2}{|c|}{$\begin{array}{l}\text { Test result: Reject } \\
\text { HO hypothesis }\end{array}$}} \\
\hline Total & 301 & $\begin{array}{r}30197.9 \\
87 \\
\end{array}$ & & & & \\
\hline
\end{tabular}

As it is seen in Table 7, the significance level of the mentioned test is $0 / 00$ and it can be claimed that the above test is statistically significant with an error of 0.05 or a confidence level of 0.95 . So $\mathrm{H} 1$ hypothesis is accepted and $\mathrm{HO}$ hypothesis is rejected. According to R2 detection factor which consist of the ratio of the explained changes by the $x$ variable to the total changes that is $0 / 956$, it can be argued that $95 \%$ of organizational adaptation changes are explained by transparency.

\section{Sixth sub hypothesis:}

$\mathrm{H} 1$ : Organizational integration has a positive and significant effect on the organizational adaptability capacity in the training and Educational system of Ilkhchi.

$\mathrm{HO}$ : Organizational integration doesn't have a positive and significant effect on the organizational adaptability capacity in the training and Educational system of Ilkhchi.

In this study, Regression test has been used to investigate the effect of dependent variable on the independent variable of this hypothesis. 
Table 8. Regression Results to Determine Organizational integration on Organizational Adaptability Capacity

\begin{tabular}{|l|r|r|r|r|r|r|}
\hline $\mathrm{R}$ & \multicolumn{2}{|l|}{$\begin{array}{l}\text { Coeffi- } \\
\text { cient of } \\
\text { detec- } \\
\text { tion } \\
\text { )R }\end{array}$} & \multicolumn{2}{|l|}{$\begin{array}{l}\text { justified Coeffi- } \\
\text { cient of detection }\end{array}$} & \multicolumn{2}{l|}{ standard error } \\
\hline
\end{tabular}

As it is seen in Table 8 and 9 the significance level of the mentioned test is 0/00 and it can be claimed that the above test is statistically significant with an error of 0.05 or a confidence level of 0.95 . So H1 hypothesis is accepted and $\mathrm{HO}$ hypothesis is rejected. According to R2 detection factor which consist of the ratio of the explained changes by the $x$ variable to the total changes that is 0/940, it can be argued that $94 \%$ of organizational adaptation changes are explained by organizational integration.

Table 9. Conclusion of the hypotheses results

\begin{tabular}{|c|c|c|c|c|}
\hline $\begin{array}{l}\text { Accept or } \\
\text { reject the } \\
\text { hypothesis }\end{array}$ & $\begin{array}{l}\text { Coefficient } \\
\text { of detec- } \\
\text { tion )R2( }\end{array}$ & $\begin{array}{l}\text { significance } \\
\text { level }\end{array}$ & hypothesis & Row \\
\hline Accept & 0.985 & $0 / 000$ & $\begin{array}{l}\text { main hy- } \\
\text { pothesis }\end{array}$ & 1 \\
\hline Accept & .912 & $0 / 000$ & $\begin{array}{l}\text { First sub } \\
\text { hypothesis }\end{array}$ & 2 \\
\hline Accept & .954 & $0 / 000$ & $\begin{array}{l}\text { Second sub } \\
\text { hypothesis }\end{array}$ & 3 \\
\hline Accept & .954 & $0 / 000$ & $\begin{array}{l}\text { Third sub } \\
\text { hypothesis }\end{array}$ & 4 \\
\hline Accept & .946 & $0 / 000$ & $\begin{array}{l}\text { Fourth sub } \\
\text { hypothesis }\end{array}$ & 5 \\
\hline Accept & .956 & $0 / 000$ & $\begin{array}{l}\text { Fifth sub } \\
\text { hypothesis }\end{array}$ & 6 \\
\hline Accept & .940 & $0 / 000$ & $\begin{array}{l}\text { Sixth sub } \\
\text { hypothesis }\end{array}$ & 7 \\
\hline
\end{tabular}

\section{RESULTS AND DISCUSSION}

According to the results of hypotheses test by Regression test, it was determined that: Individual orientation, organizational fairness, power sharing, ethical guidance, transparency and organizational integrity, regarding the detection factor of $\mathrm{R} 2,98 \%$ of organizational adaptation changes are explained and affected by changes in the ethical leadership in the training and Educational system of Ilkhchiand it shows that whatever the ethical leadership is paid more attention, the organizational adaptability capacity will be increased in the training and Educational system of Ilkhchiand also the findings of the present study are consistent with the findings of research entitled "The Energy Empowerment Model and Creativity of Employees through Ethical Leadership" [8-10].The results of this study showed that ethical leadership in the workplace improves employees' ability, energy and creativity (dimension of organizational adaptability) in the workplace. Also Abbaszadeh and Budaghi [12, 13-15], in studying of the effect of ethical leadership on organizational adaptability capacity (Case study: employees of Tabriz University), based on findings of regression analysis showed that dimensions of role resolution, people orientation, ethical guidance and the role of ethical leadership on the dependent variable (organizational adaptability capacity) is significant which is in line with the findings of this study.

Ganderson and Holinag [16-17] also believe that adaptability capacity is necessary to social environment systems survive and it is also crucial to overcome uncertainty and instability. Because organizations with adaptive capacity have this potential that 
predict and respond to changes and after the crisis, they will return to healthy resource management. Knowing and building adaptability capacity can help organizations to adapt and learn from changes, and also to know the next changes.

Calchon et al. [18-19], have other researches with the title of Ethical Leadership in Work: Development and validation of multiple measurement instruments of ethical leadership has been done. The findings of research showed that ethical leadership has crucial role in the performance and improvement of organizational behavior.

And also in numerous studies, a significant relationship between the dimensions of ethical leadership and organizational adaptability has been reported. However, the systematic study has not been expanded in the subject of ethical leadership and its relationship with various variables and factors that are influencing on it.

\section{CONCLUSION}

The results indicate that the hypothesis was confirmed, indicating that the components of the individual's orientation, organizational justice, power sharing, moral guidance, role clarity and organizational integration of organizational adaptability 98 percent of changes in education is explained and the city ILKHCHI it has an effect.

Improvements/Applications: the results show that the attention is given to ethical leadership, organizational adaptability capacity increases in education Ilkhchi city. And findings with the findings of Golparvar, colleagues, Abbas-Zadeh and Bvdaqy is consistent.

\section{REFERENCES}

1. Asadi, A. Goudarzi, R. Ghorbani. The relationship between adaptability and organizational participation among experts in the physical education organization of the ISLAMIC republic of Iran. Journal of Motion and Exercise Science. 2010; 7(14), 141-150.

2. S.M. Alvani, G.R. Memarzadeh, M. Alborzi, H. Kazemi. Presentation of spiritual leadership model in Iran's administrative system. Journal of Public Administration. 2012; 5 (1), 21-40. https://doi.org/10.2205 9/jipa.2013.35546

3. HajiPour, B., M. Moradi. Organizational Flexibility and Performance: Case Study of ARAK Industrial Estate Manufacturing Organizations. Improvement Management Studies. 2010; 22(62), 143-161.

4. Dervish H, Farzaneh Dukht (2010), Leader-member exchange, feelings of energy, and involvement in: Creative work, Public Administration, 2 (5), 21-38.

5. S.H. Zahedi, H. Ebrahimpour, H. Khalili. The role of transformational leadership on business performance: a study in Tehran Gas Company. Public Administration. 2013; 5 (1), 111-128.

6. Rastegar. Investigating the relationship between organizational culture and knowledge management (case study: national oil refining and distribution company of Iran). 2010.

7. M. Brow, I. Trevino, D, Harrison. Ethical leadership: asocial learning perspective for construct development and testing. Organizational Behavior and Decision Processes. 2005; 97, 117-134. https://doi.org/10.1016/ j.obhdp.2005.03.002

8. M. Brown, L. Trevino. Ethical leadership: a review and future directions. The Leadership Quarterly. 2006; 17, 595-616. https:// 
doi.org/10.1016/j.leaqua.2006.10.004

9. M. Brown. Misconceptions of ethical leadership: how to avoid potential pitfalls. Organizational Dynamics. 2007; 36(2), 140155. https://doi.org/10.1016/j.orgdyn.2007. 03.003

10. De Hoogh, D. De Hartog. Ethical and despotic leadership, relationships with leader's social responsibility, top management team effectiveness and subordinates optimism: A multi - method study. The Leadership Quarterly. 2008; 19, 297-311. https://doi.org/10.1016/j.leaqua.2008.03.002

11. D.R. Denison, W.S. Neal. Denison organizational culture survey, facilitator guide. Published by Denison Consulting, LLC. 2011; 1-60.

12. T. Karakose. High school teachers perceptions regarding principals ethical leadership in turkey. Asia Pacific Education Review. 2007; 8(3), 464-477. https://doi.org/ 10.1007/BF03026474

13. The power of a lollipop. Available in: http://edba.dauphine.fr/file/admin/media theque/site/edba/pdf/Feena May EDBA t hesis Dauphine 2010.pdf. Date accessed: 03/12/2010.

14. K. Mcmanus. The relationship between ethical leadership, attachment orientation and gender in organization. Dissertation for the Degree of Doctor of Philosophy Clinical Psychology, Walden University. 2011; 1-24. 15. J. McCann, H. Roger. Ethical leadership and organization an analysis of leadership in the manufacturing industry based on the perceived leadership integrity scale. Journal of Business Ethics. 2009; 87(2), 211-20. https://doi.org/10.1007/s10551-008-9880-3

16. D. Mayer, M. Kuenzi, R. Greenbaum, M. Bardes, R. Salvador. Organization behavior and human decision processes. Organizational Behavior and Human Decision Pro- cesses. 2009; 1-13.

17. Ogunfowora, B. (2009). The consequences of ethical leadership: comparisons with transformational leadership and abusive supervision. Thesis for the Degree of Doctor of Philosophy, University of Calgary, documented in university of Hong Kong library. Available online: http://sunzi.lib.hku. hk/ER/detail/hkul/4983201

18. C. Ponnu, G. Tennakoon. The association between ethical leadership and employee outcomes: the MALASIAN case. Electronic Journal of Business Ethics and Organization Studies. 2009; 14(1), 21-32.

19. C. Resick, P. Hanges, M. Dickson, J. Mitchelson. A cross-cultural examination of the endorsement of ethical leadership. Journal of Business Ethics. 2006; 63(4), 345-359. https://doi.org/10.1007/s10551$\underline{005-3242-1}$

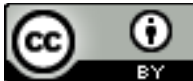

License information: This is an openaccess article distributed under the terms of the Creative Commons Attribution License, which permits unrestricted use, distribution, and reproduction in any medium, provided the original work is properly cited.

Article received on December 28, 2017.

Evaluated July 26,2019.

Accepted on August 05, 2019.

Published on August 07, 2019.

How cite this article (ABNT):

RAHIMI, Golamreza; BOHLOOLI, Nader; ESKANDARZADEH, Tohid. The effect of development of ethical leadership on organizational adaptability capacity, education and training organization - case study: ILKHCHI city of Iran. Estação Científica (UNIFAP), Macapá, v. 8, n. 3, p. 89-98, Sept./Dec. 2018. 